\title{
Development of Learning Media for Google Classroom Session in Madrasah
}

\author{
Hilyah Ashoumi ${ }^{1}$, Syahir Naashiruddin ${ }^{2}$, Ahmad Ahsanul Khuluq ${ }^{3}$ \\ 1,2,3 Universitas KH. A. Wahab Hasbullah \\ ${ }^{1}$ hira@unwaha.ac.id, ${ }^{2}$ syahirnashiruddin@gmail.com, ${ }^{3}$ aakhuluq@gmail.com
}

\begin{abstract}
This research aims to develop teaching materials for google classroom sessions at MTs and MA Nizhamiyah Ploso Jombang. Data collection techniques using questionnaires, validation sheets, and pretest-posttest questions. Therefore, researchers used the $R \& D$ method to process questionnaires and the Pairet Sample Test to determine student learning outcomes and meaningful treatment in researching each variable. The research was conducted on $307^{\text {th }}$ grade students of Islamic Cultural History subject MTs Nizhamiyah and $3011^{\text {th }}$ grade students of MA Nizhamiyah Fiqh subject. The results of the research conducted state that: (1) From the average of all the aspects asked in class 7 SKI subject is $69.6 \%$ and in class 11 Fiqh subject is $75 \%$, both of which mean feasible It is concluded that learning using Google Classroom learning media at MTs and MA Nizhamiyah Ploso is said to be feasible. (2) The mean score of the pretest class 7 subject to SKI was 52.8, while the posttest score was 68.5 and the mean score of the pretest class 11 Subject Fiqh was 48.1, while the posttest score was 68.1. Based on the table of paired samples test, the significance value is $<0.05$, indicating that there is a significant influence on the differences in treatment given during the pretest and posttest in Islamic Cultural History subjects MTs Nizhamiyyah and Fiqih MA Nizhamiyyah Ploso Jombang.
\end{abstract}

Keywords: Fiqh, Google Classroom, Islamic Cultural History, Learning Media

\begin{abstract}
Abstrak
Tujuan penelitian ini adalah untuk mengembangkan media pembelajaran melalui sarana google classroom di MTs dan MA Nizhamiyah Ploso Jombang. Teknik pengumpulan data menggunakan angket, lembar validasi serta soal pretestposttest. Oleh karena itu peneliti menggunakan metode R\&D untuk pengolahan angket dan paired sample test untuk mengetahui hasil pembelajaran siswa dan juga mengenai adanya perlakuan yang bermakna dalam melakukan penelitian di setiap variabelnya. Penelitian dilakukan pada 30 siswa kelas 7 mata pelajaran Sejarah Kebudayaan Islam MTs Nizhamiyah dan 30 siswa kelas 11 mata pelajaran Fikih MA Nizhamiyah. Hasil penelitian yang dilakukan menyatakan bahwa: (1) Dari rata-rata semua aspek yang ditanyakan pada kelas 7 mapel SKI adalah $69,6 \%$ dan pada kelas 11 mapel Fikih adalah 75\% yang kedua rata-rata tersebut berarti Layak. Disimpulkan bahwa pembelajaran menggunakan media pembelajaran Google Classroom di MTs dan MA Nizhamiyah Ploso dikatakan Layak. (2) Rata-rata dari hasil nilai pretest kelas 7 mapel SKI adalah 52,8 sedangkan dari nilai posttest adalah 68,5 dan rata-rata dari hasil pretest kelas 11
\end{abstract}


mapel Fikih adalah 48,1 sedangkan nilai posttest sebesar 68,1. Berdasarkan tabel paired sample test, nilai signifikansi adalah $<0.05$ menunjukkan bahwa adanya pengaruh yang bermakna terhadap perbedaan perlakuan yang diberikan saat pretest dan posttest di mata pelajaran Sejarah Kebudayaan Islam MTs Nizhamiyyah dan Fikih MA Nizhamiyyah Ploso Jombang.

Kata Kunci: Fikih, Google Classroom, Media Pembelajaran, Sejarah Kebudayaan Islam

\section{Introduction}

Quality education has a strategic role to become an investment in human resource development. ${ }^{1}$ Therefore, there must be a reconstruction and formulation of educational design that, in the end, supports the birth of the golden generation of the Indonesian nation can be realized. The learning process in madrasah whose success is determined by changes in students' attitudes from not knowing to know, from being less suitable to being good, ${ }^{2}$ during this one year, experienced new challenges in the process of implementing learning. This is due to the spread of Covid-19, which resulted in implementing learning being required through online learning. ${ }^{3}$ The effect of changes in the process of implementing online learning resulting from the impact of Covid-19 has different effects on students ranging from learning motivation to student learning evaluations. ${ }^{4}$ Schools and teachers must make learning easy for students to understand with a learning process that is not boring through online applications. ${ }^{5}$

There are still many madrasah teachers' homework related to unfinished learning, for example about the use of conventional methods, which results in decreased student enthusiasm and motivation to learn. ${ }^{6}$ Where are promising results from learning are driven by the motivation and enthusiasm of students in learning the subjects taught by the teacher. $^{7}$

\footnotetext{
${ }^{1}$ F. R. Dongoran, "Paradigma Membangun Generasi Emas 2045 dalam Perspektif Filsafat Pendidikan," Jurnal Tabularasa PPS UNIMED, 11(1) (Jurnal Tabularasa PPs UNIMED, 11(1), 2014).

${ }^{2}$ Noor Komari Pratiwi, "Pengaruh Tingkat Pendidikan, Perhatian Orang Tua, dan Minat Belajar Siswa terhadap Prestasi Belajar Bahasa Indonesia Siswa SMK Kesehatan di Kota Tangerang,” Pujangga 1, no. 2 (2017): 31.

${ }^{3}$ Rizqon H Syah, "Dampak Covid-19 pada Pendidikan di Indonesia: Sekolah, Keterampilan, dan Proses Pembelajaran," Salam: Jurnal Sosial dan Budaya Syar-i 7, no. 5 (2020).

${ }^{4}$ G Bambang Nugroho, "Peran Guru Bimbingan dan Konseling Dalam Pendampingan Belajar Siswa Selama Pembelajaran Online," Psiko Edukasi 18, no. 1 (2020): 73-83.

${ }^{5}$ Sarjana Pendidikan, "Implementasi Model Pembelajaran Daring pada Masa Pandemi Covid-19 di Kelas III SD PTQ Annida Kota Salatiga Tahun Pelajaran 2020 Skripsi" (2020).

${ }^{6}$ Abuddin Nata, Perspektif Islam tentang Strategi Pembelajaran (Jakarta: Kencana Prenada Media Group, 2009).

${ }^{7}$ Nurhayati Nurhayati, "Motivasi Belajar Pendidikan Agama Islam di SMA Negeri 1 Belawa Kab. Wajo (Perspektif Teori ARCS)," Lentera Pendidikan : Jurnal Ilmu Tarbiyah dan Keguruan 17, no. 2 (2014): 272280.
} 
Technology in the form of learning media has a role in increasing learning motivation. Technology is something that serves to facilitate learning and improve the performance of educators by creating, using, and managing appropriate technological processes and resources. ${ }^{8}$ If the learning is centered on the teacher and technology, then the media is used to support the presentation of teaching materials, with an attractive appearance it is inevitable that children's learning motivation increases and is not quickly bored in the learning process, so that learning effectiveness is expected to continue to increase. ${ }^{9}$ Learning media facilities convey messages in communication between learning, teaching, and teaching materials to students. These three things are the essence of the learning process in the classroom. Its implementation will be easy if supported by suitable learning media. The evaluation is also more valid if the learning media uses the right technology. ${ }^{10}$

The Google Classroom learning facility would be an alternative solution for teachers and students during the pandemic, which led to the prohibition of the face-to-face learning process. Besides being relatively easy to use, Google Classroom can also be said to be a cheap and light learning tool because it can be done through smartphones or computers/laptops; besides that, this facility has an attractive and convenient appearance because it can be applied anytime and anywhere. ${ }^{11}$ One of the positive impacts of the Google Classroom learning tool is that this platform has many features that can be actively applied to help students learn to be more active and organized in storing learning documents. $^{12}$

Based on the field conditions where the study was conducted when the learning took place, the learning process was centered on WhatsApp groups, group members consisting of all class students, and all teachers in charge of subjects in the class. There is hinders the implementation of learning; for example, students ask the teacher for a lesson or want to hold discussions about the material during the online learning hours, the implementation of learning becomes ineffective and inefficient. Therefore, students feel less accessible when learning is done in WhatsApp groups. The other side of the ineffectiveness of using

\footnotetext{
${ }^{8}$ Yaumi Muhammad, “Terminologi Teknologi Pembelajaran: Satuan Tinjauan Historis. Jurnal Terminologi Teknologi Pembelajaran,” (Jurnal Terminologi Teknologi Pembelajaran, 2016).

9 F.R. Dongoran, "Paradigma Membangun Generasi Emas 2045 dalam Perspektif Filsafat Pendidikan," Jurnal Tabularasa PPs UNIMED, 11(1).

${ }^{10}$ Ibid.

11 Deden Sutrisna, "Meningkatkan Kemampuan Literasi Mahasiswa Menggunakan Google Classroom," FON : Jurnal Pendidikan Bahasa dan Sastra Indonesia 13, no. 2 (2018): 69-78.

12 Hilyah Ashoumi and Mochammad Syafiuddin Shobirin, "Penggunaan Google Classroom pada Mata Kuliah PAI," JoEMS (Journal of Education and Management Studies) 2, no. 4 (2019): 29-34.
} 
WhatsApp is that important things such as files sent by teachers or students are not stored in separate folders, which results in an overlap between conversational discussions and assignment files so that apart from being inflexible, they also have shortcomings in the efficiency and effectiveness of the learning process. ${ }^{13}$

If examined through previous research that researchers rely on as a reference, such as the research of Kivah Aha Putra, et al. which reviews the responses of students majoring in physics and biology at UIN Maulana Malik Ibrahim Malang to the learning process with 2 learning facilities through Google Classroom and Google Meet, this study uses quantitative research methods through data collection techniques from Google Form surveys with the result that $90.1 \%$ of students are motivated. Attending lectures on the history of Islamic civilization. ${ }^{14}$ So in this study, student responses were also questioned. Not only questioned students' responses after using the Google Classroom learning tool but also questioned student responses to the development of learning media used by teachers in Google Classroom learning facilities. So to find out, researchers need to use data collection techniques through documentation and questionnaires. Documentation is vital to use in data collection techniques because, in research on the development of learning media, researchers need to validate to media experts and material experts to get valid results that the learning media developed is feasible to be applied. In this study, researchers also want to know the learning outcomes after applying learning media which is then inputted into the Google Classroom learning facility through pretest and posttest data collection techniques. Illustratively formulation of the problem above with the concept of the research carried out is illustrated by a framework of thought, which is as follows:

\footnotetext{
${ }^{13}$ Nuril Anwar and Imam Riadi, "Analisis Investigasi Forensik WhatsApp Messanger Smartphone terhadap WhatsApp Berbasis Web,” Jurnal Ilmiah Teknik Elektro Komputer dan Informatika 3, no. 1 (2017): 1.

${ }^{14}$ Misbahul Munir, Kivah Aha Putra, Ratna Nulinnaja, "Persepsi Mahasiswa pada Pembelajaran Daring melalui Pemanfaatan Google Classroom dan Google Meet di UIN Maulana Malik Ibrahim Malang," Indonesian Journal of Islamic Education Studies (IJIES) 2, no. 2 (2020): 2.
} 


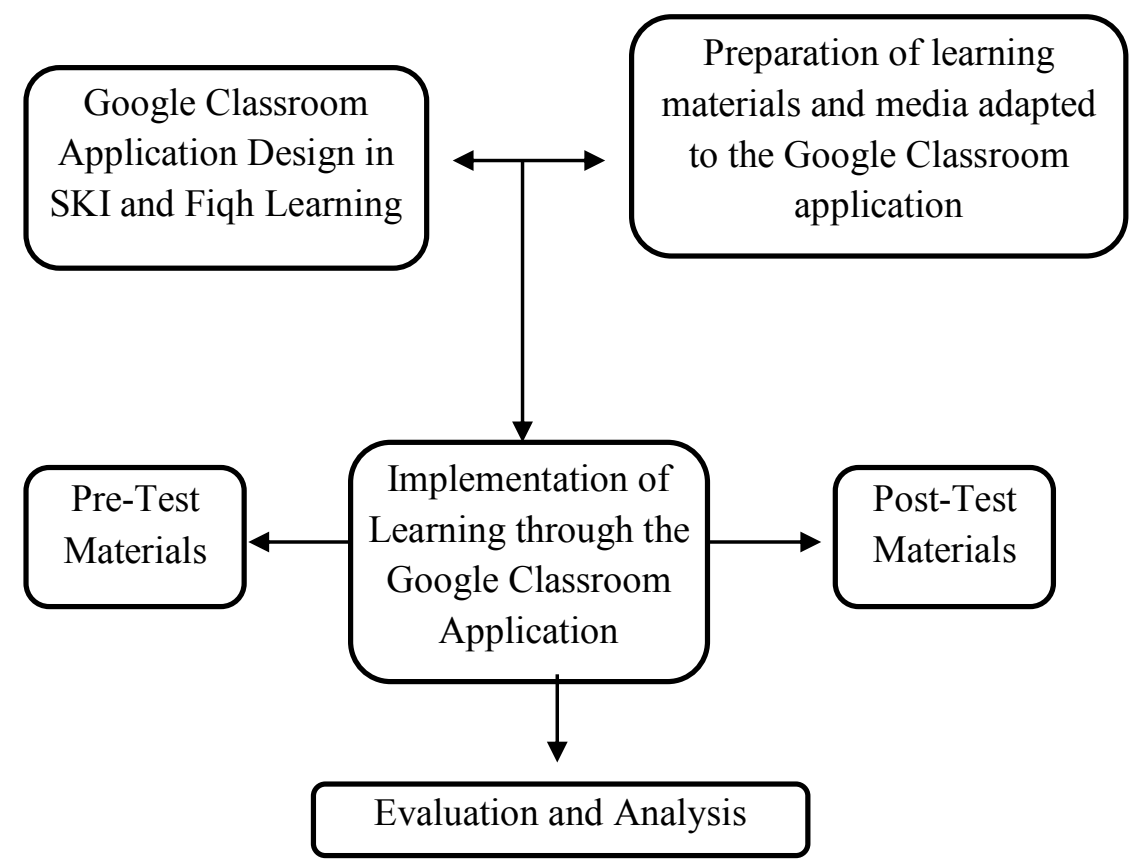

From the description of the problems above, this study aims to develop learning media through the Google Classroom application to improve student learning outcomes for MTs and MA Nizhamiyah Ploso Jombang students in 2 subjects, namely the SKI subject for $7^{\text {th }}$ grade MTs Nizhamiyah and the Fiqh subject for $9^{\text {th }}$ grade MA Nizhamiyah.

\section{Methods}

This research uses a development method to create learning media through the Google Classroom learning facility. Meanwhile, the products developed were teaching materials from the $7^{\text {th }}$ grade SKI subjects at MTs Nizhamiyah and the $9^{\text {th }}$ grade Fiqh subjects MA Nizhamiyah. Experts have developed several developments, research models. This research adopts the model developed by Borg and Gall. According to Borg \& Gall, development research consists of ten steps which include (1) needs analysis, (2) planning, (3) product draft development, (4) initial field trials, (5) revising test results, (6) field trials, (7) refinement of products resulting from field trials, (8) field implementation tests, (9) refinement of final products, and (10) dissemination and implementation. Due to limited human resources, time, and cost, the researchers modified the development steps into seven stages, namely, (1) potential and problem analysis, (2) data collection, (3) product design, (4) design validation, (5) improvement. design, (6) product trial, (7) product revision. ${ }^{15}$

\footnotetext{
${ }^{15}$ Sugiyono. Metode Penelitian Kuantitatif Kualitatif dan R\&D (Bandung: Alfabeta, 2014) 28.
} 
The potential at the research site is that online learning via smartphones is already used to it, even before the pandemic occurred. While the existing problem is the lack of student activity in learning because the learning is centered via the WhatsApp group, in which all subject teachers are causing the class atmosphere to be less active and feel less comfortable to conduct discussions about learning. Data obtained from curriculum documents and teachers include; teaching materials, lesson plans, learning media that teachers usually apply.

Product design is the step of designing the framework of a video-based learning media product that will be developed later. Meanwhile, video-based learning media products are made in three stages which include pre-production, which consists of problem identification, script creation. Production, in this stage, is carried out recording activities related to the delivery of learning materials. Postproduction, in this stage, the potential at the research site is that online

Learning via smartphones is already used to it, even before the pandemic occurred. While the existing problem is the lack of student activity in learning because the learning is centered via the WhatsApp group, in which all subject teachers are causing the class atmosphere to be less active and feel less comfortable to conduct discussions about learning. Data obtained from curriculum documents and teachers include; teaching materials, lesson plans, learning media that teachers usually apply.

Product design is the step of designing the framework of a video-based learning media product that will be developed later. Meanwhile, video-based learning media products are made in three stages which include: 1) preproduction, which consists of problem identification, script creation; 2) production, in this stage is carried out recording activities related to the delivery of learning materials; 3 ) postproduction, in this stage video editing and video finalization carried out.

Validation design, in this step, conducted feasibility test media, which instructional media has been tested to the expert of media and subject matter experts learning. Material experts analyze and assess whether the prepared material follows the Competency Standards, Basic Competencies, and Learning Objectives. In the Google Classroom learning media, media experts assess and analyze appearance, the layout of text and images, font and size, color suitability, and background selection. Media experts also tested the feasibility of the Google Classroom learning media that would be presented in the learning process. Product trials are intended to collect data that can be used as a basis for determining the level of effectiveness, efficiency, feasibility, and or attractiveness of the 
resulting product. For product, trials were carried out utilizing small group and field trials. Data collection was carried out on 30 students in each school using an instrument in the form of a questionnaire, and the researcher gave two tests, namely a pre-test and a test of learning outcomes from the use of the learning video.

The data obtained from this development research are qualitative data and quantitative data. Qualitative data, which is data in criticism and suggestions from material experts, media experts, and students, were analyzed descriptively qualitatively. Quantitative data in the form of research questionnaire data and assessment data about the Google Classroom virtual media from material experts, media experts, and students were analyzed by analytical techniques using descriptive statistics. However, there were scoring rules or scoring in evaluating the data before analyzing. The scoring rules are as follows: SB (very good) with a score of 5, B (good) with a score of 4, C (enough) with a score of 3, $\mathrm{K}$ (poor) with a score of 2 , and SK (very poor) with a score of 1 . While in the instrumentation the students' responses used assessment categories in the form of strongly disagree, disagree, agree, and also strongly agree.

The feasibility value in this study has a feasibility level between $0-20 \%$. It is said to be significantly less feasible and needs total improvement. If it gets a feasibility value of $20.01 \%-40 \%$, it is said to be less feasible and needs improvement according to the advice of the expert team. If you get a score of 40.01-60\%, the Google Classroom learning facility is said to be quite feasible and needs to be improved according to the advice of the expert team. If you get a score of $60.01-80 \%$, it is said to be suitable for use without improvement, and if you get a score of $80.01-100 \%$, the Google Classroom learning facility is categorized as very suitable to be used as a support medium for learning SKI and Fiqh subjects in the classroom. So it can be concluded for student responses, very poor criteria $=$ very unattractive, fewer criteria $=$ less attractive, sufficient criteria $=$ quite interesting, good criteria $=$ exciting, and very good criteria $=$ very interesting.

\section{Research Results}

\section{Small-Scale Test Results}

The results of small-scale trials on the early-stage Google Classroom application were carried out to 5 respondents in different classes from the class intended to be used as a research class. Besides that, it ensures that uploaded media and other features in Google Classroom can run as expected. The results of this trial were shared with the respondents in the form questionnaire. Then the details of the test results were presented in 3 aspects. The 
details of the indicators of each aspect will be explained in the subfield test results, as for the 3 aspects in the results of small-scale trials, among others; 1) Aspects of student acceptance of the ease of Google Classroom as a learning tool at MTs Nizhamiyah $76.4 \%$ the average percentage and at MA Nizhamiyah by $72 \%$ 2) Aspects of the quality of learning through google classroom at MTs Nizhamiyah on a small scale there is an average of $83,6 \%$ of 5 respondents and 84\% from MA Nizhamiyah 3) Aspects of the use of learning media in the Google Classroom learning facility, the results of the questionnaire from 5 respondents $83 \%$ stated that both at MTs Nizhamiyah and MA Nizhamiyah $79 \%$.

\section{Field Trial Results}

The result of this Field Trial is the collection of extensive group data from $7^{\text {th }}$ grade students of MTs Nizhamiyah, totaling 30 students with details of each aspect asked in the questionnaire and the percentage results of each aspect as shown in the Table 1:

\begin{tabular}{|l|c|c|}
\hline \multicolumn{1}{|c|}{ Google Classrom is Easy to Apply by Students } & MTs & MA \\
\hline Question Indicator & \% & \% \\
\hline Complete tasks faster with google classroom & $61,3 \%$ & $78 \%$ \\
\hline Improved student performance in learning & $62,6 \%$ & $71 \%$ \\
\hline Increased productivity in learning & $66 \%$ & $72 \%$ \\
\hline Bringing Benefits in the learning process & $68 \%$ & $83 \%$ \\
\hline Easy to access & $62 \%$ & $79 \%$ \\
\hline Flexible use & $62 \%$ & $76 \%$ \\
\hline Interesting & $61 \%$ & $66 \%$ \\
\hline Faster learning feedback from teacher & $62 \%$ & $79 \%$ \\
\hline Happy feeling using google classroom & $66,6 \%$ & $71 \%$ \\
\hline Average Percentage & $\mathbf{6 3 , 9 \%}$ & $\mathbf{7 5 \%}$ \\
\hline
\end{tabular}

Table 1. Student Admission to the Ease of Google Classroom

With the acquisition of percentages of $63.9 \%$ and $75 \%$ from the aspect of student acceptance of Google Classroom, it is concluded that the Google Classroom learning media is suitable for use by students at MTs and MA Nizhamiyah Ploso for learning facilities. 


\begin{tabular}{|l|c|c|}
\hline \multicolumn{1}{|c|}{ Quality Learning Through Google Classroom } & MTs & MA \\
\hline \multicolumn{1}{|c|}{ Question Indicator } & $\%$ & $\%$ \\
\hline $\begin{array}{l}\text { The main points of the material are delivered before } \\
\text { the lesson begins by teacher }\end{array}$ & $65,3 \%$ & $85 \%$ \\
\hline $\begin{array}{l}\text { There is a summary of the material that has been } \\
\text { taught in each meeting }\end{array}$ & $71,3 \%$ & $77 \%$ \\
\hline There is assignment to students & $70.3 \%$ & $83 \%$ \\
\hline $\begin{array}{l}\text { There are assessment criteria for the mastery of the } \\
\text { material for students }\end{array}$ & $68 \%$ & $83 \%$ \\
\hline Use of various learning methods & $67,3 \%$ & $74 \%$ \\
\hline Use of various learning strategies & $70 \%$ & $77 \%$ \\
\hline $\begin{array}{l}\text { Use of various learning media on several different } \\
\text { materials }\end{array}$ & $69,3 \%$ & $76 \%$ \\
\hline Giving appreciation to students who have good grades & $70,6 \%$ & $77 \%$ \\
\hline There is an explanation of learning objectives & $70,6 \%$ & $79 \%$ \\
\hline $\begin{array}{l}\text { There is the use of wi-fi, projectors and other } \\
\text { supporting facilities by teachers }\end{array}$ & $82,6 \%$ & $79 \%$ \\
\hline $\begin{array}{l}\text { With the learning media used by the teacher the class } \\
\text { atmosphere becomes fun }\end{array}$ & $76 \%$ & $76 \%$ \\
\hline There are two-way activities in the learning process & $74,6 \%$ & $80 \%$ \\
\hline $\begin{array}{l}\text { The learning process becomes more effective and } \\
\text { efficient with the learning media used by the teacher }\end{array}$ & $74 \%$ & $75 \%$ \\
\hline Average Percentage & $\mathbf{7 1 , 5 \%}$ & $\mathbf{7 8 \%}$ \\
\hline
\end{tabular}

Table 2. Quality of Learning Through Google Classroom

With the acquisition of percentages of $71.5 \%$ and $78 \%$, it can be said that the quality of learning by using Google Classroom facilities is said to be good.

\begin{tabular}{|c|c|c|}
\hline $\begin{array}{c}\text { Use of Learning Media in Google Classroom } \\
\text { Learning Tools }\end{array}$ & MTs & MA \\
\hline Question Indicator & $\%$ & $\%$ \\
\hline $\begin{array}{l}\text { Use of language that is good and correct and effective } \\
\text { so that learning media are easy to understand. }\end{array}$ & $72,6 \%$ & $80 \%$ \\
\hline There is novelty and uniqueness of learning media & $71,3 \%$ & $68 \%$ \\
\hline $\begin{array}{l}\text { There is an increase in students' motivation in learning } \\
\text { the material after using instructional media }\end{array}$ & $68 \%$ & $80 \%$ \\
\hline There is an attractiveness of color in learning media & $71,3 \%$ & $72 \%$ \\
\hline $\begin{array}{l}\text { There is conformity in the media is appropriate with } \\
\text { learning materials }\end{array}$ & $74 \%$ & $84 \%$ \\
\hline Text on the media can be read well & $72 \%$ & $80 \%$ \\
\hline $\begin{array}{l}\text { Illustrations are able to describe the content of the } \\
\text { material }\end{array}$ & $72,6 \%$ & $84 \%$ \\
\hline Neat media design & $79,3 \%$ & $84 \%$ \\
\hline Average Percentage & $72,6 \%$ & $79 \%$ \\
\hline
\end{tabular}

Table 3. Use of Learning Media in Learning Google Classroom Tools 
With the acquisition of $72.6 \%$ and $79 \%$ of learning media in the Google Classroom learning, the facility is said to be good, and the students enjoy the learning.

\section{Data Analysis}

Data were analyzed from this research through 2 methods of data collection, namely the results of the documentation and the results of the students' pretest and posttest scores.

\section{Documentation}

Criticisms and suggestions from experts, both material and media, in developing a product are essential to implement so that the media and teaching materials developed have standard validation.

\section{a. Material Expert Validation}

Assessment of teaching materials developed by material experts includes 3 aspects, namely, aspects of content feasibility, presentation feasibility, and contextual feasibility. The material expert who became the validator in this study was 1 lecturer of the Islamic religious education study program at $\mathrm{KH} \mathrm{A}$. Wahab Hasbullah University who has the appropriate competence in the material being developed. The calculation of the percentage score of each criterion in the questionnaire given by the researcher to the material expert was then calculated using a likert scale. The results of the initial material validation are listed in Table 4:

\begin{tabular}{|c|c|c|}
\hline Aspect & Percentage (\%) Ideality & Criteria \\
\hline Content Feasibility & $74,6 \%$ & Eligible \\
\hline Presentation Feasibility & $77,5 \%$ & Eligible \\
\hline Contextual Assessment & $70 \%$ & Eligible \\
\hline Average & $74,05 \%$ & Eligible \\
\hline
\end{tabular}

Table 4. Results of Material Expert Validation Early Stage

The results of the material expert's assessment are categorized as very feasible if $\mathrm{X}>$ $80 \%$; feasible if $61 \%<\mathrm{X} 80 \%$; quite feasible if $41 \%<\mathrm{X} 60 \%$ less feasible if $21 \%<\mathrm{X}$ $40 \%$ and very less feasible if $X 20 \%$. From the calculation data on the three aspects of the initial stage material validation, it can be seen that the content feasibility aspect gets a percentage of $74.6 \%$ with appropriate criteria, $77.5 \%$ presentation feasibility aspect with appropriate criteria, and in the contextual assessment aspect with a percentage of $70 \%$ with eligible criteria, thus obtained the average number of total aspects of $74.05 \%$ with proper criteria. Suggestions for improvement from material experts are that the content of the material is not very relevant, and after receiving advice from material experts, and the examples given in the material are following daily activities. 
b. Media Expert Validation

Assessment of the media is also essential to get the appropriate validation standard, and this is done by filling out an assessment questionnaire sheet consisting of 14 statements on the graphic feasibility aspect. Validation session, the validator provides suggestions for improving the sound of the recording in the video, which is in the 4.30 to 5.30 minutes. After making revisions from media experts and assessing that the video media is well made and very interesting, the video media deserves to be tested. The results of the final stage of media expert validation are presented in table 5 as follows:

\begin{tabular}{|c|c|l|}
\hline Aspect & Percentage (\%) Ideality & \multicolumn{1}{|c|}{ Criteria } \\
\hline Feasibility of Graphics & $77,14 \%$ & Eligible \\
\hline Average & $77,14 \%$ & Eligible \\
\hline
\end{tabular}

Table 5. Final Stage Media Expert Validation Results

Based on the results of table 5 above, a score of $77.14 \%$ is obtained with appropriate criteria. So the average score for this aspect is $77.14 \%$, which means that the Google Classroom media is declared worthy as a learning tool.

c. Results of Student Pretest and Posttest:

\begin{tabular}{|c|c|c|c|}
\hline \multicolumn{2}{|c|}{ Pretest Score } & \multicolumn{2}{|c|}{ Posttest Score } \\
\hline Value & Number of Students & Value & Number of Students \\
\hline $30-40$ & 6 & $30-40$ & 2 \\
\hline $41-50$ & 7 & $41-50$ & 3 \\
\hline $51-60$ & 11 & $51-60$ & 5 \\
\hline $61-70$ & 5 & $61-70$ & 7 \\
\hline $71-80$ & 1 & $71-80$ & 9 \\
\hline $81-90$ & 0 & $81-90$ & 4 \\
\hline Total Students & 30 & Total Students & 30 \\
\hline
\end{tabular}

Table 6. Results of Pretest and Posttest SKI Subjects

\begin{tabular}{llll}
\hline & & Pretest & Posttest \\
\hline $\mathrm{N}$ & Valid & 30 & 30 \\
& Missing & 0 & 0 \\
Mean & & 52.8333 & 68.5000 \\
Std. Error of Mean & & 2.01551 & 2.59476 \\
Median & 55.0000 & 70.0000 \\
Mode & 55.00 & $70.00^{\mathrm{a}}$ \\
Std. Deviation & & 11.03938 & 14.21206 \\
Variance & & 121.868 & 201.983 \\
Range & 45.00 & 50.00 \\
Minimum & & 30.00 & 40.00 \\
Maximum & & 75.00 & 90.00 \\
Sum & & 1585.00 & 2055.00 \\
Percentiles & 25 & 45.0000 & 60.0000 \\
& 50 & 55.0000 & 70.0000 \\
& 75 & 60.0000 & 80.0000 \\
\hline
\end{tabular}

a. Multiple modes exist. The smallest value is shown

Table 7. Statistic of Pretest and Posttest 
The average of the results of the pretest score is 52.8, while the posttest score is 68.5.

\begin{tabular}{|l|l|l|l|}
\hline \multicolumn{2}{|c|}{ Pretest Score } & \multicolumn{2}{c|}{ Posttest Score } \\
\hline \multicolumn{1}{|c|}{ Value } & Number of Students & \multicolumn{1}{c|}{ Value } & Number of Students \\
\hline $30-35$ & 3 & $50-55$ & 3 \\
\hline $36-40$ & 4 & $56-60$ & 4 \\
\hline $41-45$ & 5 & $61-65$ & 5 \\
\hline $46-50$ & 6 & $66-70$ & 6 \\
\hline $51-55$ & 5 & $71-75$ & 5 \\
\hline $56-60$ & 4 & $76-80$ & 4 \\
\hline $61-65$ & 3 & $81-85$ & 3 \\
\hline Total Students & $\mathbf{3 0}$ & Total Students & $\mathbf{3 0}$ \\
\hline
\end{tabular}

Table 8. Results of the Pretest and Posttest of the Fiqh Subjects

\begin{tabular}{|c|c|c|c|}
\hline & & Pretest & Posttest \\
\hline \multirow[t]{2}{*}{$\mathrm{N}$} & Valid & 30 & 30 \\
\hline & Missing & 0 & 0 \\
\hline Mean & & 48,1000 & 68,1000 \\
\hline Std. Error of Mean & & 1,75011 & 1,75011 \\
\hline Median & & $48,5000^{\mathrm{a}}$ & $68,5000^{\mathrm{a}}$ \\
\hline Mode & & 50,00 & 70,00 \\
\hline Std. Deviation & & 9,58573 & 9,58573 \\
\hline Variance & & 91,886 & 91,886 \\
\hline Skewness & &,- 090 &,- 090 \\
\hline Std. Error of Skewness & &, 427 &, 427 \\
\hline Kurtosis & &,- 793 &,- 793 \\
\hline Std. Error of Kurtosis & &, 833 &, 833 \\
\hline Range & & 35,00 & 35,00 \\
\hline Minimum & & 30,00 & 50,00 \\
\hline Maximum & & 65,00 & 85,00 \\
\hline Sum & & 1443,00 & 2043,00 \\
\hline
\end{tabular}

a. Calculated from grouped data.

\section{Table 9. Statistic of Pretest and Posttest}

The average value of the pretest score is 48.1 , while the posttest score is 68.1 . Paired sample test, T-test sample test is used to compare the difference between two means of two paired samples with the assumption that the data is typically distributed. Paired samples come from the same subject. Each variable is taken when the situation is different. Decision making. Significant value (2-tailed) $<0.05$ indicates a significant difference between the initial and final variables. That shows a significant effect on the differences in the treatment given to each variable. The significance value (2-tailed) $>0.05$ indicates no significant difference between the initial and final variables. It shows that there is no significant effect on the difference in treatment given to each variable. 


\begin{tabular}{|l|l|l|l|l|l|}
\hline \multicolumn{2}{|l|}{} & Mean & N & Std. Deviation & \multicolumn{1}{|l|}{ Std. Error Mean } \\
\hline $\begin{array}{l}\text { Paired Sample } \\
\text { Statistic I }\end{array}$ & Pretest & 52.8333 & 30 & 11.03938 & 2.01551 \\
\cline { 2 - 6 } & Posttest & 68.5000 & 30 & 14.21206 & 2.59476 \\
\hline $\begin{array}{l}\text { Paired Sample } \\
\text { Statistic II }\end{array}$ & Pretest & 48,1000 & 30 & 9,58573 & 1,75011 \\
\hline & Posttest & 68,1000 & 30 & 9,58573 & 1,75011 \\
\hline
\end{tabular}

Table 10. Statistical Description

The table 10 is a statistical description of the average value of the pretest and posttest with the information that Paired Samples Statistics I is a statistical descriptive from the SKI MTs Nizhamiyah folder, and Paired Samples II is a statistical descriptive from the Fiqh MA Nizhamiyah folder.

\begin{tabular}{llll} 
& N & Correlation & Sig. \\
\hline Pair Sample Correlation I & Pretest and posttest 30 & .759 & .000 \\
\hline Pair Sample Correlation II & Pretest and posttest 30 &,- 159 &, 402 \\
\hline
\end{tabular}

Table 11. Relation Between Initial variable and Final Variable

The table 11 shows whether there is a relationship between the initial variable and the final variable, namely pretest and posttest. Suppose the significant value $<0.05$ means a relationship between the pretest and posttest. If the significant value is $>0.05$, there is no relationship between pretest and posttest. The table 11 has a significance value of $<0.05$, so there is a relationship between pretest and posttest.

\begin{tabular}{|c|c|c|c|c|c|c|c|c|c|}
\hline & & \multicolumn{5}{|c|}{ Paired Differences } & \multirow{3}{*}{$\mathbf{t}$} & \multirow{3}{*}{ df } & \multirow{3}{*}{$\begin{array}{l}\text { Sig. (2- } \\
\text { tailed) }\end{array}$} \\
\hline & & \multirow[t]{2}{*}{ Mean } & \multirow{2}{*}{$\begin{array}{l}\text { Std. } \\
\text { Deviation }\end{array}$} & \multirow{2}{*}{$\begin{array}{l}\text { Std. } \\
\text { Error } \\
\text { Mean } \\
\end{array}$} & \multicolumn{2}{|c|}{$\begin{array}{l}95 \% \text { Confidence Interval } \\
\text { of the Difference }\end{array}$} & & & \\
\hline & & & & & Lower & Upper & & & \\
\hline PST I & $\begin{array}{l}\text { Pretest and } \\
\text { Posttest }\end{array}$ & -15.66667 & 9.25997 & 1.69063 & -19.12440 & -12.20894 & -9.267 & 29 & .000 \\
\hline PST II & $\begin{array}{l}\text { Pretest and } \\
\text { Posttest }\end{array}$ & $-20,00000$ & 14,59334 & 2,66437 & $-25,44924$ & $-14,55076$ & $-7,506$ & 29 &, 000 \\
\hline
\end{tabular}

Table 12. Paired Sample Test (PST)

The conclusion is based on the table of paired samples test. The significance value is $<0.05$, indicating a significant effect on the difference in treatment given to each of these variables. Indicates a significant effect on the treatment given during the pretest and posttest.

\section{Discussion}

During the pandemic, which requires the learning process to be carried out online at this time, professional teachers are required to carry out educational efforts to prepare their 
students to face life in the present and in the future where skills and competencies in managing and filtering information are essential and needed. ${ }^{16}$ Among the teacher's efforts in preparing student competencies related to information management and screening, namely by using the use of learning approaches that are applied to social media. ${ }^{17}$ In cyberspace, social media is a means of communication that is carried out online by its users so that if applied in learning, the role of the teacher as an adult becomes essential to supervise and guide students' meaning regarding online learning media which has no limits. ${ }^{18}$ In this online learning situation, educators can use an application on Google, namely Google Classroom. Google Classes are virtual classes, similar to physical classes. This first-class google service, integrated with Google Docs and Google Drive services, is simple and free, making it easier for users to benefit from these services.

Designing an excellent way to use Google Classroom will meet students' needs for a more engaging process, understanding and practice, and interaction with the material introduced. ${ }^{19}$ In this way, material that has initially been rigid and unpublished can be interacted with through Google Classroom and become an output in learning, so that the acquisition of learning materials in children becomes more interesting. According to Hidayat and Sudibyo, Google Classroom has several advantages, including assessment management, processing speed, paperless, and many other conveniences that cause many institutions to use these educational facilities. The functions given to educators are similar to conventional classes in the teaching process; asking questions (making problems), doing homework (making assignments), and issuing announcements (posting announcements) are not limited to this. Even Google Classroom also provides multimedia services (videos streaming) to help students understand the learning material. ${ }^{20}$

\footnotetext{
${ }^{16}$ Siti Wahyuni, Dina Dahniary Sholekah, "Pemanfaatan Media Sosial dalam Proses Pembelajaran di SMPN 1 Mojo Kediri," Indonesian Journal of Islamic Education Studies (IJIES) 2, no. 1 (2019): 52.

17 Rijki Ramdani, Munawar Rahmat, and Agus Fakhruddin, "Media Pembelajaran E-Learning dalam Pembelajaran Pendidikan Agama Islam Di SMA Laboratorium Percontohan UPI Bandung," Tarbawy: Indonesian Journal of Islamic Education 5, no. 1 (2018): 47.

${ }^{18}$ Ismail Ismail, "Peran Guru Pendidikan Agama Islam dalam Mengantisipasi Dampak Penggunaan Media Sosial bagi Siswa Sekolah Menengah Pertama," IQRO: Journal of Islamic Education 1, no. 2 (2018): 105120.

${ }^{19}$ Diemas Bagas Panca Pradana, "Pengaruh Penerapan Tools Google Classroom pada Model Pembelajaran Project Based Learning terhadap Hasil Belajar Siswa," It-Edu 2, no. 01 (2017).

${ }^{20}$ Astrid Krisdayanthi I Ketut Sudarsana, Ni Gusti Ayu Made Yeni Lestari I Komang Wisnu Budi Wijaya, I Gede Dharman Gunawan Komang Yuli Andayani, Komang Trisnadewi, Ni Made Muliani Ni Putu Sasmika Dewi, I Ketut Suparya, and I Made Putra Aryana Niluh Ari Kusumawati, I Putu Yoga Purandina, Ni Komang Sutriyanti Ni Nyoman Sudiani, Ni Wayan Adnyani, S. M. Fernanda Iragraha I Made Astra Winaya, Gede Agus Siswadi, Covid-19 Perspektif Pendidikan, ed. Aria Prima Dewi PF Kadek, Acta Universitatis Agriculturae et Silviculturae Mendelianae Brunensis, vol. 53 (Denpasar: Yayasan Kita Menulis, 2015).
} 
Seeing the attractiveness of the Google Classroom facility as a forum for learning media, the products developed in this study consisted of 2 types of media: e-learning Google Classroom and video text. The researcher uploads a text video that has been designed previously by adjusting the teaching materials. Then after receiving formal legal from the experts (validators) on the Google Classroom page, the researcher uploads the results of developing learning media in the google classroom facility through the use of computer media connected to the internet network, in addition to on computer and laptop media, accessing learning media on the Google Classroom facility can also be accessed via a smartphone.

The product developed consists of 2 types, namely e-learning Google Classroom and video text. The researcher will upload a text video on the Google Classroom page because the researcher uploads the results of the development of learning media in Google Classroom. This learning media uses a computer connected to the internet network. Besides, the computer can also be accessed using a smartphone. The learning media in this study presents the following matters:

1) Learning media in the SKI folder contained in the video text edited using the Kinemaster Application version 4.16.5.18945. GP, which can be downloaded on Playstore/Appstore. The advantage of the Kinemaster application is that it can edit videos by entering text, images, and various animations. Moreover, it can also record sound to explain the meaning of the image that the teacher wants to explain through narration with voice recordings that are available in the application. ${ }^{21}$ While the Learning Media in the Fiqh folder uses the 2010 version of PowerPoint, which contains learning material, and is converted into a video through the Bandicam application version 4.5 Portable. The advantages of this learning media include that students can efficiently and effectively understand the material presented, practical because it allows it to be used both in large classes and classes with a small number of students, has many exciting features in it such as; clip art, images, animation, color, and sound features. ${ }^{22}$

2) The learning material delivered by the teacher of the SKI subject is about the background establishment of the Umayyah Dynasty and the history of the founding of

\footnotetext{
${ }^{21}$ H Khaira, "Pemanfaatan Aplikasi Kinemaster sebagai Media Pembelajaran Berbasis ICT," Prosiding Seminar Nasional Pembelajaran Bahasa (2021): 39-44, http://digilib.unimed.ac.id/id/eprint/41218.

22 Nurhidayati, "Media Power Point dan Pemanfaatannya dalam Proses Pembelajaran Bahasa Arab," Prosiding Konferensi Nasional Bahasa Arab V (2019): 463-470, http://prosiding.arabum.com/index.php/konasbara/article/view/515.
} 
the Umayyah Dynasty. Learning videos on the Umayyah Dynasty SKI Chapter subject were uploaded by researchers on the Youtube page and linked to the Google Classroom facility as an online interactive medium between educators and students. While in Fiqh subjects, the material taught is about the understanding, terms, pillars, and kinds of divorce, Khulu, Fasakh, Iddah, and Rujuk. Furthermore, discuss the wisdom of divorce. Then the researchers linked the material on the Google Classroom page as an online interactive medium between educators and students. The material is presented online using youtube on the link https://youtu.be/_qCua4D5qOU

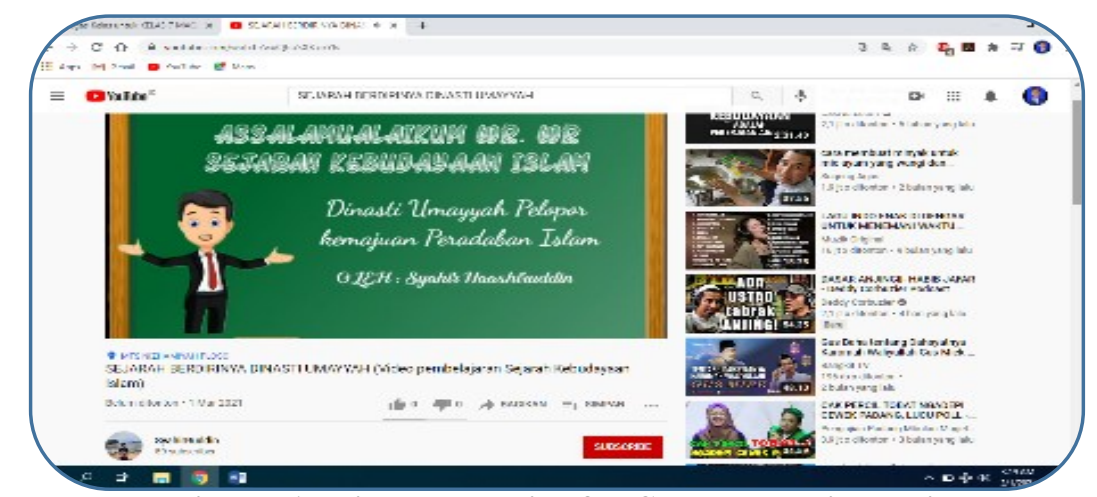

Figure 1. Video material for SKI MTs Nizhamiyah

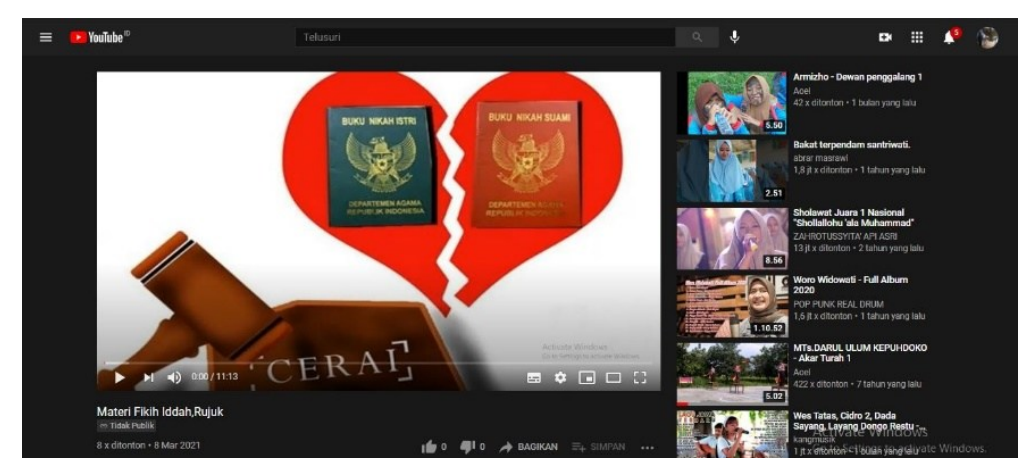

Figure 2. Video of MA Nizhamiyah's Fiqh Learning Material

3) The learning outcomes test is presented online, which is linked to the google form and can also be accessed through the website.

The results obtained from this study indicate that students have high enthusiasm for learning when learning is carried out in a fun and challenging atmosphere so that enthusiasm for learning media for them is one of the learning motivations for teachers so that the learning materials presented are not dull for students. Through the use of this exciting learning media, which then improves student learning outcomes.

\section{Conclusion}

The development of learning media through Google Classroom facilities during the Covid-19 pandemic and responding to student responses at MTs and MA Nizhamiyah 
Ploso, which were seen both from student admissions at the ease of Google Classroom, Application of learning media through Google Classroom facilities, and Quality of learning through Google Classroom, was declared feasible to be applied as a learning tool in MTs and MA Nizhamiyah Ploso.

Student learning outcomes through Google Classroom media experienced many developments in students' understanding of the material being taught. This research was shown using the pretest and posttest results of the students of MTs Nizhamiyah on the SKI map; the average score of the pretest was 52.8, while the posttest score was 685 . Meanwhile, the MA Nizhamiyah with an average of 48.1 for the pretest and 68.1 for the posttest in the Fiqh subject. and calculated using SPSS showed that the significance was $<0.05$, indicating that there was a significant effect between before using the media and after using the media.

\section{References}

Abuddin Nata. Perspektif Islam tentang Strategi Pembelajaran. Jakarta: Kencana Prenada Media Group, 2009.

Anwar, Nuril, and Imam Riadi. "Analisis Investigasi Forensik WhatsApp Messanger Smartphone terhadap WhatsApp Berbasis Web." Jurnal Ilmiah Teknik Elektro Komputer dan Informatika 3, no. 1 (2017): 1.

Ashoumi, Hilyah, and Mochammad Syafiuddin Shobirin. "Penggunaan Google Classroom pada Mata Kuliah PAI." JoEMS (Journal of Education and Management Studies) 2, no. 4 (2019): 29-34.

Bagas Panca Pradana, Diemas. "Pengaruh Penerapan Tools Google Classroom pada Model Pembelajaran Project Based Learning terhadap Hasil Belajar Siswa.” It-Edu 2, no. 01 (2017).

Dina Dahniary Sholekah, Siti Wahyuni. "Pemanfaatan Media Sosial dalam Proses Pembelajaran di SMPN 1 Mojo Kediri." Indonesian Journal of Islamic Education Studies (IJIES) 2, no. 1 (2019): 52.

Dongoran, F. R. "Paradigma Membangun Generasi Emas 2045 dalam Perspektif Filsafat Pendidikan." Jurnal Tabularasa PPs UNIMED, 11(1). Jurnal Tabularasa PPs UNIMED, 11(1), 2014.

I Ketut Sudarsana, Ni Gusti Ayu Made Yeni Lestari I Komang Wisnu Budi Wijaya, Astrid Krisdayanthi, I Gede Dharman Gunawan Komang Yuli Andayani, Komang Trisnadewi, Ni Made Muliani Ni Putu Sasmika Dewi, I Ketut Suparya, and I Made Putra Aryana Niluh Ari Kusumawati, I Putu Yoga Purandina, Ni Komang Sutriyanti Ni Nyoman Sudiani, Ni Wayan Adnyani, S. M. Fernanda Iragraha I Made Astra Winaya, Gede Agus Siswadi. Covid-19 Perspektif Pendidikan. Edited by Aria Prima Dewi PF Kadek. Acta Universitatis Agriculturae et Silviculturae Mendelianae Brunensis. Vol. 53. Denpasar: Yayasan Kita Menulis, 2015.

Ismail, Ismail. "Peran Guru Pendidikan Agama Islam dalam Mengantisipasi Dampak 
Penggunaan Media Sosial bagi Siswa Sekolah Menengah Pertama." IQRO: Journal of Islamic Education 1, no. 2 (2018): 105-120.

Khaira, H. "Pemanfaatan Aplikasi Kinemaster sebagai Media Pembelajaran Berbasis ICT." Prosiding Seminar Nasional Pembelajaran Bahasa (2021): 39-44. http://digilib.unimed.ac.id/id/eprint/41218.

Misbahul Munir, Kivah Aha Putra, Ratna Nulinnajah. "Persepsi Mahasiswa pada Pembelajaran Daring melalui Pemanfaatan Google Classroom dan Google Meet di UIN Maulana Malik Ibrahim Malang." Indonesian Journal of Islamic Education Studies (IJIES) 2, no. 2 (2020): 2.

Muhammad, Yaumi. "Terminologi Teknologi Pembelajaran: Satuan Tinjauan Historis. Jurnal Terminologi Teknologi Pembelajaran." Jurnal Terminologi Teknologi Pembelajaran, 2016.

Nugroho, G Bambang. "Peran Guru Bimbingan dan Konseling dalam Pendampingan Belajar Siswa Selama Pembelajaran Online.” Psiko Edukasi 18, no. 1 (2020): 73-83.

Nurhayati, Nurhayati. "Motivasi Belajar Pendidikan Agama Islam di SMA Negeri 1 Belawa KAB. Wajo (Perspektif Teori ARCS)." Lentera Pendidikan: Jurnal Ilmu Tarbiyah dan Keguruan 17, no. 2 (2014): 272-280.

Nurhidayati. "Media Power Point dan Pemanfaatannya dalam Proses Pembelajaran Bahasa Arab." Prosiding Konferensi Nasional Bahasa Arab V (2019): 463-470. http://prosiding.arab-um.com/index.php/konasbara/article/view/515.

Pendidikan, Sarjana. "Implementasi Model Pembelajaran Daring pada Masa Pandemi Covid-19 di Kelas III SD PTQ Annida Kota Salatiga Tahun Pelajaran 2020 Skripsi” (2020).

Pratiwi, Noor Komari. "Pengaruh Tingkat Pendidikan, Perhatian Orang Tua, dan Minat Belajar Siswa terhadap Prestasi Belajar Bahasa Indonesia Siswa SMK Kesehatan di Kota Tangerang." Pujangga 1, no. 2 (2017): 31.

Ramdani, Rijki, Munawar Rahmat, and Agus Fakhruddin. "Media Pembelajaran ELearning dalam Pembelajaran Pendidikan Agama Islam di SMA Laboratorium Percontohan UPI Bandung." Tarbawy: Indonesian Journal of Islamic Education 5, no. 1 (2018): 47.

Sugiyono. Metode Penelitian Kuantitatif Kualitatif dan R\&D. Bandung: Alfabeta, 2014.

Sutrisna, Deden. "Meningkatkan Kemampuan Literasi Mahasiswa Menggunakan Google Classroom." FON : Jurnal Pendidikan Bahasa dan Sastra Indonesia 13, no. 2 (2018): 69-78.

Syah, Rizqon H. "Dampak Covid-19 pada Pendidikan di Indonesia: Sekolah, Keterampilan, dan Proses Pembelajaran.” Salam: Jurnal Sosial dan Budaya Syar-i 7, no. 5 (2020). 